\title{
Nursing performance in the policy transfer of directly observed treatment of tuberculosis
}

\author{
ATUAÇÃO DA ENFERMAGEM NA TRANSFERÊNCIA DA POLÍTICA DO TRATAMENTO \\ DIRETAMENTE OBSERVADO DA TUBERCULOSE
}

\section{ACTUACIÓN ENFERMERA EN EL TRASLADO DE LA POLÍTICA DEL TRATAMIENTO DIRECTAMENTE OBSERVADO EN LA TUBERCULOSIS}

\author{
Káren Mendes Jorge de Souza ${ }^{1}$, Lenilde Duarte de Sá ${ }^{2}$, Laís Mara Caetano da Silva ${ }^{3}$, \\ Pedro Fredemir Palha ${ }^{4}$
}

\begin{abstract}
Objective: Analyzing the policy transfer of directly observed treatment of tuberculosis from the perspective of nursing. Method: This is a descriptive study with qualitative approach, which had 10 nurses of the Family Health Strategy in São Paulo as subjects. The interviews were carried out between May and June 2013, and were adopted the technique of thematic content analysis and the referential of policy transfer. Results: On the signification of this treatment, are related the senses of disciplinary monitoring, the bond and approximation to the context of patients' lives. Operationally, nurses, community health agents and nursing technicians stand out as agents of implementation of this policy, developing multiple actions of user embracement. The nurse is evidenced as an educator in health, leader in the family health team, and capable of creating emotional bond with users. Conclusion: It was found that the innovations proposed in the treatment are incipient in the daily work of nurses.
\end{abstract}

\section{DESCRIPTORS}

Tuberculosis

Directly observed therapy

Primary Health Care

Health policy

Public health nursing

\section{RESUMO}

Objetivo: Analisar a transferência de política do tratamento diretamente observado da tuberculose sob a perspectiva da Enfermagem. Método: Estudo descritivo, com abordagem qualitativa que teve como sujeitos 10 enfermeiras da Estratégia Saúde da Família do município de São Paulo. As entrevistas foram realizadas entre maio e junho de 2013. Adotou-se a técnica da análise de conteúdo temática e o referencial da transferência de políticas. Resultados: Na significação desse tratamento, relacionam-se sentidos de monitoramento disciplinar, vínculo e aproximação ao contexto de vida do doente. Operacionalmente, o enfermeiro, o agente comunitário de saúde e o técnico de enfermagem destacamse como agentes da implementação dessa política, desenvolvendo ações múltiplas e acolhedoras. O enfermeiro é evidenciado como educador em saúde, líder na equipe de saúde da família e capaz de produzir vínculo afetivo com o usuário. Conclusão: Identificou-se que as inovações propostas ao tratamento são incipientes no cotidiano de trabalho dos enfermeiros.

\section{DESCRITORES \\ Tuberculose \\ Terapia diretamente observada \\ Atenção Primária à Saúde \\ Política de saúde \\ Enfermagem em saúde pública}

\section{RESUMEN}

Objetivo: Analizar el traslado de política del tratamiento directamente observado en la tuberculosis bajo la perspectiva de la Enfermería. Método: Estudio descriptivo, con abordaje cualitativo que tuvo como sujetos 10 enfermeras de la Estrategia Salud de la Familia del municipio de São Paulo. Las entrevistas se llevaron a cabo entre mayo y junio de 2013. Se adoptó la técnica del análisis de contenido temático y lo referencial del traslado de políticas. Resultados: En la significación de dicho tratamiento, se relacionan sentidos de monitoreo disciplinar, vínculo y aproximación al marco de vida del enfermo. Operacionalmente, el enfermero, el agente comunitario de salud y el técnico de enfermería se destacan como agentes de la implantación de esa política, desarrollando acciones múltiples y acogedoras. Al enfermero se le evidencia como educador en salud, líder del equipo de salud de la familia y capaz de producir vínculo afectivo con el usuario. Conclusión: Se identificó que las innovaciones propuestas al tratamiento son incipientes en el cotidiano de trabajo de los enfermeros.

\section{DESCRIPTORES \\ Tuberculosis \\ Terapia por observación diecta \\ Atención Primaria de Salud \\ Política de salud \\ Enfermería en salud pública}

\footnotetext{
${ }^{1}$ Post-Doctorate, School of Nursing of Ribeirão Preto, Universidade de São Paulo, Ribeirão Preto, SP, Brazil. ${ }^{2}$ Associate Professor, Department of Nursing of Public Health and Psychiatry, Universidade Federal da Paraíba, João Pessoa, PB, Brazil. ${ }^{3}$ PhD Student, Post-Graduate Program in Public Health Nursing, School of Nursing of Ribeirão Preto, Universidade de São Paulo, Ribeirão Preto, SP, Brazil. ${ }^{4}$ Associate Professor, Department of Maternal-infant Nursing and Public Health, School of Nursing of Ribeirão Preto, Universidade de São Paulo, Ribeirão Preto, SP, Brazil.
} 


\section{INTRODUCTION}

Tuberculosis (TB) is a contagious disease related to poverty, the presence of urban agglomeration areas and situations of vulnerability in health, with epidemiological importance in the Brazilian scenario and worldwide. In the last two decades, although there has been an overall reduction in the number of cases and deaths, TB is still recognized as a neglected disease, particularly due to the scarcity of actions aimed at tackling the social determinants involving it.

In Brazil, in 2013, the National Tuberculosis Control Program (NTCP) has established two priorities for combating the disease: the expansion of diagnosis with deployment of new technology and the strengthening of TB actions in Primary Care (PC). As technological innovation, the Ministry of Health introduced the rapid molecular test for TB (RMT-TB) in some services of the Unified Health System (SUS - Sistema Único de Saúde), because it is a more accurate and efficient method for detecting within two hours, the Mycobacterium tuberculosis and mutations associated with resistance to rifampicin ${ }^{(1)}$. In PC, the prevention, diagnosis and treatment of TB should be guided by strategic principles for the organization of the health system, with accessible services that are also cost effective, functionally integrated and based on health needs of individuals, families and the community.

Recent national and international scientific studies recommend the continuous monitoring of patients with TB, with supervision of drug therapy by a health professional, aiming at improving the quality of health care, the enhancement of treatment adherence and for preventing the emergence of tuberculostatic resistant bacteria ${ }^{(2-5)}$. However, there is research showing that the difficulties in the operation of directly observed treatment (DOT) compromise the achievement of positive impacts related to the rates of cure and abandonment of treatment, and recommend attention to regional specificities, since the operationalization of DOT is heterogeneous depending on the different geographical spaces where it is developed ${ }^{(6-8)}$.

In the constitution of the worldwide known strategy called Directly Observed Treatment, Short-course (DOTS), the DOT articulates with four other pillars: case detection by sputum smear microscopy among respiratory symptoms; regular drug supply; a recording and reporting system that ensures the assessment of treatment results, and the government commitment of inserting TB control as a priority among the health policies ${ }^{(3)}$.

The DOTS strategy, which involves a set of policies, was transferred to the Brazilian context in 1998 and some states, such as São Paulo, adhered to its guidelines in the same year ${ }^{(9)}$. It is noteworthy that initially, the political commitment of incorporating the DOTS in the context of SUS was induced by financial incentives provided to priority municipalities for TB control, in which the transfer of money was linked to bonuses on the development of supervised treatment. From 1999 to 2006, funds were periodically transferred as specific items however, since 2007 , the transfer of money has been from the national fund to the municipal health fund ${ }^{(7)}$.

In 2000, the TB becomes part of the group of activities of the Department of Primary Care (DPC) of the Ministry of Health. The municipalities, which have assumed the management of public health policies since 1993, start to manage and operate the actions of TB control, including the DOT, in coordination with the preferred gateway to SUS that is the Family Health Strategy (FHS). The perceived obstacles in the decentralization process refer mainly to the maintenance of financial and material resources to sustain the strategy, in addition to technical qualification requirements for health workers, aiming at developing these actions at the local level ${ }^{(7,10)}$. In this sense, this study aimed to analyze the policy transfer of DOT for TB control in the FHS from the perspective of nurses.

By highlighting nursing in this study, is valued the history linking the work of nurses with prevention and control of $\mathrm{TB}^{(11)}$, while contextualizing the role of these professionals in the FHS, conceiving it as a promising scenario of practice and knowledge that brings challenges, opportunities for autonomy and innovation.

With this research based on the international framework of policy transfer, the objective is to advance in knowledge production in Nursing, in light of a theoretical framework that proposes thinking innovations, in other words, the incorporation of new knowledge and practices in health services. According to this perspective, the results of this study can signal alternatives for improving the execution of DOT, focused primarily on the actions of monitoring and evaluation in the FHS and respecting the particularities of each place where this policy is being developed.

\section{METHOD}

This is an operational research, which investigates strategies, interventions, instruments or knowledge that can promote quality, coverage, effectiveness or performance of health systems or programs, thus aiming for changes in policy and practice of health services ${ }^{(12-13)}$. In order to understand this reality, a descriptive study with qualitative approach was carried out, having as subjects the nurses of ten basic health units, with FHS belonging to three Technical Supervisions of Health, of the Regional Coordination of Health (CRS) North, in the capital of the state of São Paulo.

The CRS North was selected based on the observation that the incidence rate for TB and the trend indicated by the adjusted percentage change (APC) in the period between 2004 and 2009, pointed it as the CRS with highest reduction of TB coefficient of incidence (-3.5\%), followed by the eastern region $(-2.5 \%)$, the Midwest $(-2.4 \%)$, 
Southeast (-1.4\%) and South (-1.1\%). In addition, there is the fact that, according to the Municipal Health Secretary of São Paulo, in the same period, the CRS North was recognized as one of the regions of significant increase in FHS coverage ${ }^{(14)}$.

The following inclusion criteria were previously defined for the sample: (1) being a nurse of the FHS; (2) having at least one year of experience in the implementation of DOT.

For the production of empirical material, was used the technique of semistructured interviews with 10 participants, in the period between May $21^{\text {st }}$ and June $25^{\text {th }}$ 2013. The interviews were audio recorded and guided by a script with data for the characterization of participants, plus four research questions, namely: What do you think about directly observed treatment (DOT) for tuberculosis? How is your family health team organized to carry out DOT? How do you evaluate the contribution of nursing to DOT? and Thinking about your daily work, which adequacy or innovation do you consider necessary to promote patient adherence to TB treatment?

Except for the second interview, which was conducted in an educational institution at the request of the nurse, the others were made in the health units where the study participants worked. The average duration of the interviews was 12 minutes.

The recruitment of participants and sample definition began with the identification of the 'pure' basic health units in the CRS North, which were those with the FHS only that had notified TB cases in the period from $01 / 11 / 2012$ to $24 / 04 / 2013$ and carried out DOT. Later, were excluded the units in which was not possible to schedule the interview after three phone contacts with the team nurse.

The qualitative sample was closed with the verification of theoretical saturation ${ }^{(15)}$, when the researcher identified some redundancy of themes in the speeches of the interviewees therefore, it was not considered relevant to persist in data collection.

The material of crude language was organized and analyzed by the technique of content analysis - thematic modality ${ }^{(16)}$, according to which the themes are identified, classified, gathered in empirical categories (categorization) and discussed in the light of the research objectives, theoretical framework and relevant literature. The notion of topic is linked to a statement about a particular subject. It is the unit of meaning corresponding to the units of record of transcribed interviews that can be graphically presented by a word, phrase or summary ${ }^{(16)}$. The themes emerging from the empirical material were coordinated with the policy transfer approach, thus developing a new analytical perspective on operational studies.

The framework of policy transfer investigates how the transfer of a particular policy occurs, including the health policies that are carried out in a certain time and/or space to another time and/or space, in a movement that seeks to understand the context and the influences exerted on this process. This is an innovative perspective, and the qualitative research is of great importance as an ally to deepen the understanding of this phenomenon $^{(12,17)}$.

The policy transfer is also a model of political change that occurs in five levels, namely: transnational, international, national, regional and local. Operationally, the transfer involves different individuals and/or groups in their different stages. They are called 'official' transfer agents, participating in the development and evaluation of the transfer of a given policy, especially during the implementation stage ${ }^{(18)}$. In this study, considering the policy of DOT, already transferred to the Brazilian context and, locally, to the city of São Paulo, we value the participation of FHS nurses as important agents in its implementation.

The research was carried out according to the required ethical standards. The study was approved by the Research Ethics Committee of the institution as well as by the Research Ethics Committee of the Municipal Health Secretary of São Paulo, under protocol number CAAE: 07310812.0.0000.5393.

\section{RESULTS}

As for the characterization of the research subjects, the 10 nurses participating were aged 36.1 years (25$47)$ on average, at the time of data collection. They also had experience in FHS of 6.5 years (1-12) on average. Among them, only two did not have specialization in the area of Public Health nor in Family Health.

With regard to the connection of the surveyed nurses with the Technical Health Supervision of CRS North, their work units were distributed as follows: seven in Freguesia do Ó/Brasilândia, two in Santana/Jaçanã, one in Casa Verde/Cachoeirinha, zero in Pirituba/Perus and zero in Vila Maria/Vila Guilherme.

Regarding the content analysis of the transcribed interviews, were produced four categories and subcategories expressing the classification and grouping by similarities and differences of themes in the language material analyzed.

The Chart 1 presents the speeches on DOT and shows that all participants emphasized the fact that this treatment modality is effective for the monitoring and cure of sick people. Other important recurring themes refer to the bonding between users and health professionals (50\%), the reduction of dropouts (30\%) and the experience of putting health care professionals in face of social challenges, such as the abusive use of drugs and alcohol, and family maladjustment (30\%). 
Chart 1 - Themes on DOT according to subcategories of analysis and the occurrence per interviews - São Paulo, Brazil, 2013

\begin{tabular}{|l|l|c|}
\hline \multicolumn{1}{|c|}{ Subcategory } & \multicolumn{1}{|c|}{ Themes } & $\begin{array}{c}|c| \\
\text { Occurrence by number } \\
\text { of interviews }\end{array}$ \\
\hline \multirow{3}{*}{$\begin{array}{l}\text { DOT approximates health } \\
\text { professionals and TB patients, } \\
\text { creating bond and reducing cases } \\
\text { of treatment discontinuation. }\end{array}$} & DOT leads to the cure of patients. & $10 / 10$ \\
\cline { 2 - 3 } & DOT creates bond between health professionals and users. & $5 / 10$ \\
\cline { 2 - 3 } & DOT decreases treatment dropout. & $3 / 10$ \\
\hline \multirow{2}{*}{$\begin{array}{l}\text { DOT expresses feelings of } \\
\text { permanent supervision and } \\
\text { discipline of patients. }\end{array}$} & DOT enables the early identification of users' health needs. & $2 / 10$ \\
\hline \multirow{3}{*}{$\begin{array}{l}\text { DOT shows difficulties inherent } \\
\text { in the life context of TB patients } \\
\text { that become challenges to the } \\
\text { health team. }\end{array}$} & Patients must follow the 'line' of treatment. & $10 / 10$ \\
\cline { 2 - 3 } & $\begin{array}{l}\text { The compulsory hospitalization should be recommended for patients with active TB } \\
\text { who do not adhere to treatment. }\end{array}$ & $1 / 10$ \\
\cline { 2 - 3 } & Drug addiction. & $3 / 10$ \\
\cline { 2 - 3 } & Family maladjustment. & $3 / 10$ \\
\cline { 2 - 3 } & $\begin{array}{l}\text { DOT provides social benefits for patients and their families (transportation and basic } \\
\text { food basket). }\end{array}$ & $3 / 10$ \\
\hline
\end{tabular}

When the interviewed nurses were asked about how teamwork was organized for the operationalization of DOT, 12 themes emerged from their speeches, as shown in chart 2. In this category, the most prominent themes express the follow-up of TB patients in the course of treatment, namely: the completion of a medical record for frequency registration and control of the daily intake of medication (100\%); observation of ingestion of antituberculosis medication at home by the community health agent (CHA) $(100 \%)$; the observation in the health service carried out by the nursing technician (60\%); flexibilization of the observation site (60\%); and the provision of monthly medical or nursing consultation for user evaluation (60\%). The results presented in Chart 2 produce evidence that DOT was not just a transferred policy, but also triggered innovations in the process of teamwork.

In the view of the interviewees, nursing excels at carrying out DOT due to their actions with leadership, humanization and commitment, as well as because of actions developed in health education. The most recurrent themes that support this interpretation are inserted in chart 3: the nurse develops emotional bonds with the service user (50\%); and the nurse guides the patient on the treatment time, the consequences of therapeutic abandonment, adverse reactions to drugs, living with family, feeding and other topics (50\%).

Chart 2 - Themes on the operationalization of DOT according to subcategories of analysis and the occurrence per interviews - São Paulo, Brazil, 2013

\begin{tabular}{|c|c|c|}
\hline \multicolumn{3}{|c|}{ Category 2: Operationalization of DOT } \\
\hline Subcategory & Themes & $\begin{array}{l}\text { Occurrence by number } \\
\text { of interviews }\end{array}$ \\
\hline \multirow{5}{*}{$\begin{array}{l}\text { Actions related to DOT as a policy } \\
\text { of primary care. }\end{array}$} & $\begin{array}{l}\text { Observation and recording of frequency of daily intake of medication using a } \\
\text { spreadsheet. }\end{array}$ & $10 / 10$ \\
\hline & Monthly medical or nursing consultation for evaluation of users. & $6 / 10$ \\
\hline & Assessment and control exams (smear and culture). & $3 / 10$ \\
\hline & Carrying out searches of patients absent in scheduled visits. & $2 / 10$ \\
\hline & Guidance on the disease to the person under treatment. & $2 / 10$ \\
\hline \multirow{3}{*}{$\begin{array}{l}\text { Agents of the policy transfer of } \\
\text { DOT in the FHS. }\end{array}$} & Community health agents stand out in DOT at home. & $10 / 10$ \\
\hline & Nursing technicians stand out in DOT in the health units. & $6 / 10$ \\
\hline & $\begin{array}{l}\text { Nurses, nursing technicians and the community health agents stand out in the } \\
\text { search of users missing the consultations. }\end{array}$ & $2 / 10$ \\
\hline \multirow{4}{*}{$\begin{array}{l}\text { Approximation developed by } \\
\text { health professionals. }\end{array}$} & $\begin{array}{l}\text { Health professionals offer flexibility for DOT site (health unit or home), accord- } \\
\text { ing to the preference of users. }\end{array}$ & $6 / 10$ \\
\hline & Nurses encourage the modality of DOT in the first nursing consultation. & $3 / 10$ \\
\hline & $\begin{array}{l}\text { Health professionals use a range of social benefits (basic food basket and trans- } \\
\text { portation) as a stimulus to continue the treatment. }\end{array}$ & $3 / 10$ \\
\hline & $\begin{array}{l}\text { Health professionals are concerned with the embracement of TB patients under } \\
\text { treatment. }\end{array}$ & $3 / 10$ \\
\hline
\end{tabular}


Chart 3 - Themes on the contribuition of nursing to DOT according to subcategories of analysis and the occurrence per interviews São Paulo, Brazil, 2013

\begin{tabular}{|c|c|c|}
\hline \multicolumn{3}{|c|}{ Category 3: Contributions of Nursing to DOT } \\
\hline Subcategory & Themes & $\begin{array}{l}\text { Occurrence by number of } \\
\text { interviews }\end{array}$ \\
\hline Nursing in health education. & $\begin{array}{l}\text { Nurses guide patients on the treatment time, the consequences of therapeutic } \\
\text { dropout, adverse reactions to drugs, living with the family and adequate food. }\end{array}$ & $5 / 10$ \\
\hline \multirow{5}{*}{ Nursing Care. } & The nurses develop emotional bonds with service users. & $5 / 10$ \\
\hline & The nurses carry out searches of users missing the consultations. & $4 / 10$ \\
\hline & The nurses build a unique treatment plan, tailored to the needs and profile of users. & $2 / 10$ \\
\hline & The nurses encourage the continuity of supervised treatment. & $2 / 10$ \\
\hline & $\begin{array}{l}\text { The nurses have an adhesion agreement with users regarding the minimum } \\
\text { amount of supervised medication ( } 3 \text { times per week) and the grant of the food } \\
\text { basket benefit. }\end{array}$ & $1 / 10$ \\
\hline \multirow{3}{*}{$\begin{array}{l}\text { Nursing leadership in the } \\
\text { teamwork in the FHS. }\end{array}$} & Without nursing, DOT would not happen as effectively as it is happening. & $4 / 10$ \\
\hline & The nursing stands out in the work of the FHS. & $3 / 10$ \\
\hline & The nurses supervise the work of community health agents of DOT at home. & $1 / 10$ \\
\hline
\end{tabular}

Chart 4 - Themes on innovation for DOT according to subcategories of analysis and the occurrence per interviews - São Paulo, Brazil, 2013.

\begin{tabular}{|c|c|c|}
\hline \multicolumn{3}{|c|}{ Category 4: Innovations for DOT } \\
\hline Subcategory & Themes & $\begin{array}{l}\text { Occurrence by number } \\
\text { of interviews }\end{array}$ \\
\hline $\begin{array}{l}\text { Appreciation of community health } \\
\text { agents. }\end{array}$ & $\begin{array}{l}\text { Offer some benefit to community health agents doing DOT at home to motivate } \\
\text { success in treatment monitoring. }\end{array}$ & $1 / 10$ \\
\hline Empowerment of TB patients. & $\begin{array}{l}\text { Replace the donation of social benefits by the development of patient } \\
\text { accountability for their health. }\end{array}$ & $1 / 10$ \\
\hline \multirow{2}{*}{$\begin{array}{l}\text { Continuing education to health } \\
\text { professionals. }\end{array}$} & Periodic technical qualifications for professionals involved with DOT. & $1 / 10$ \\
\hline & $\begin{array}{l}\text { Monthly discussions and exchange of experiences among health professionals } \\
\text { of different units, mediated by managers of the Municipal Health Secretary. }\end{array}$ & $1 / 10$ \\
\hline \multirow{2}{*}{ Nursing consultation. } & $\begin{array}{l}\text { For patients with difficulty in treatment adherence, organize a follow-up } \\
\text { consultation every } 10 \text { or } 15 \text { days. }\end{array}$ & $1 / 10$ \\
\hline & $\begin{array}{l}\text { Clarify for the TB patients about the disease and treatment at the first consulta- } \\
\text { tion or at diagnosis. }\end{array}$ & $1 / 10$ \\
\hline Intersectoriality. & $\begin{array}{l}\text { Count on partnerships external to the health unit (Pastoral care of children and } \\
\text { community leaders) to sensitize users and the community about fighting TB. }\end{array}$ & $1 / 10$ \\
\hline $\begin{array}{l}\text { Coordination of care to TB } \\
\text { patients. }\end{array}$ & Coordination of assistance through the Web-TB. & $1 / 10$ \\
\hline
\end{tabular}

When asked about the need for innovations in DOT policy in the context of the FHS, the study participants raised various themes, in which they suggest the actions needed to promote patient adherence to TB treatment. The themes are shown in Chart 4.

\section{DISCUSSION}

Considering that the policy transfer is a process in which a program is partially or fully transferred to another context, and may undergo a series of adaptations by the decision makers who have the responsibility to shape public policy ${ }^{(17)}$, nurses and other health professionals of the FHS can identify the health needs of TB patients, when carrying out DOT, to qualify its performance.

With the perspective of innovating a health care practice resulting from the transfer of a given policy, the concept of health necessities shall be managed in relation to the TB patient, taking into account that such necessities are affected by the configuration of space occupied by these individuals in society, and therefore, requiring to overcome the dichotomy individual/society in order to
Nursing performance in the policy transfer of directly observed treatment of tuberculosis Souza KMJ, Sá LD, Silva LMC, Palha PF 
express the quality and effectiveness of care ${ }^{(19)}$. In this process, nurses must also recognize and value the situations of vulnerability experienced by TB patients, to better assist and protect them. The vulnerability analysis allows knowing and understanding the differences on how each individual experiences the health-disease process, which has sociocultural determination.

It is a fact that many scholars consider DOT as a favorable policy to therapy adherence and prevention of the clinical, epidemiological and social consequences of an irregular treatment ${ }^{(2-5)}$. However, it is essential to deepen the discussion about the subjective experience of patient adherence to TB treatment, which can be considered laborious for the healthcare professional, tiring for the patient and difficult for both ${ }^{(6,9)}$. In this respect, the results of some studies, like the present investigation, indicate that the emotional bond developed between TB patients and health professionals is crucial to improve the quality of care and achieve the therapeutic outcome of cure ${ }^{(20-22)}$. The bond between these subjects generates the atmosphere of trust and shared responsibility for the success of the treatment plan. The subjectivity aspect of the ill person is something to be considered in the policy transfer of DOT in order to value not just the technical and regulatory aspects.

Considering the political-care context of the interviewed nurses practice, it is noteworthy that one of the fundamental principles of the FHS is to create bond between the health team and the mentioned community, aiming to maintain the care of individuals and their families throughout time, through a proactive attitude towards the health-disease problems ${ }^{(23)}$. Thus, the bond, as a dimension of primary care, suggests an interdependence and depends on how the teams are responsible for people's health. Nowadays, the FHS is considered for its potential in promoting the creation of a bond between professionals and people with $\mathrm{TB}^{(22)}$, to strengthen and facilitate the monitoring of measures for disease control, especially the DOT.

A study carried out in João Pessoa, capital of the state of Paraíba, when analyzing the perceptions of FHS nurses on the supervised TB treatment, showed that this treatment modality, in addition to creating a bond between users and health professionals, approximates the members of the family health team, strengthening the cooperation among them ${ }^{(23)}$.

The guideline of interdisciplinarity should be considered in the process of policy transfer. The interdisciplinary teamwork is particularly important when complex situations arise in the context of life of patients with TB, such as drug addiction, alcoholism, family crises and other social problems, as reported in this research. Any policy that does not value the social determinants of health, even if implemented, is at risk of not being effective.

It is necessary to better distribute the DOT policy in the health system under the design of a network of care. The scientific literature shows DOT as the most effective strategy to increase the cure rates of TB. This modality of treatment supervision has very low dropout rates when compared to self-administered treatment, with particularly good results among groups at high risk for abandonment, such as alcoholics, the homeless population, injecting drug addicts and people with positive serology for the human immunodeficiency virus (HIV) or with a history of treatment abandonement ${ }^{(24)}$.

Concerning the operationalization of DOT, the Ministry of Health recommends four types of supervision: at home, at the clinic, in the prison system and the shared modality ${ }^{(25)}$. However, it is important that the health team negotiates with patients the conduction of treatment according to their health needs ${ }^{(6-9)}$ and desires, as expressed by one of the study participants.

Thus, in the operationalization of DOT, it is essential that the process of policy transfer supplies information for health professionals with which they can consider the life context of TB patients and their families, since this approximation can qualify the listening therapy developed by health professionals. In this perspective, the community health agent stands out for residing and working in the same territory of health service users, sharing the organizational practice and cultural production of the community. Thus, the community health agents bring important contributions to the recognition of the health needs of TB patients, however, these professionals must be qualified within the Tuberculosis Control Plan - $\operatorname{TCP}^{(6,9)}$, especially when faced with infectious diseases such as TB, which is of difficult control and has specificities regarding its representation to the ill people and their families.

Regarding the contribution of nursing to the DOT policy, in this study, the participants highlighted, besides the previously discussed bond, the role played by nurses as educators and leaders in the FHS.

It is known that guiding TB patients, their families and the community about the disease, its prevention and treatment favors the empowerment of these individuals in coping with the disease process and the epidemiological situation of $\mathrm{TB}^{(6,9)}$. Clarifying about the treatment time and the possible drug adverse reactions is particularly important to avoid the therapeutic abandonment ${ }^{(21)}$.

Study participants recognize that over the years, nursing has assumed a prominent role in DOT as well as, more broadly, in the FHS, which admittedly expands the work possibilities of these professionals, who are committed to human development, social transformation and an interactive, multidimensional and interdisciplinary practice ${ }^{(26)}$

From the viewpoint of policy transfer, it is worth noting that the information, knowledge and innovation are interconnected dimensions in the transfer process of a policy, in which the objects can be classified as the following: the political goals; structure and content; administrative 
techniques; institutions; ideologies; ideas, attitudes and concepts; and, finally, negative experiences ${ }^{(17)}$. In this study, we focused on the ideas, as well as attitudes and concepts of nurses about DOT, which were explored in the four issues of the interview script.

In this sense, the implementation of DOT in Primary Care Services depends on the transfer of information, knowledge and governance, involving policymakers, administrators and those who operationalize the daily work of health services, which demands an adjustment period, in addition to the innovative and entrepreneurial capacity of nurses in the FHS. In this study, the new thoughts and procedures related to DOT are linked to the autonomy of patients, the performance of the health team and the coordination of care with a sense of integrality.

For operational purposes, there is a common technical base to guide that at the end of treatment, patients must have had at least twenty-four drug ingestions directly observed by health professionals in the attack phase (first two months), and forty-eight in the maintenance phase ${ }^{(25)}$. However, special attention should be given to the context of the territory, where people live, work and develop their health-disease process, permeated by subjectivity.

The work in health and nursing is linked to intersubjectivity, through which we constitute ourselves as unique individuals. Therefore, in the encounter of subjectivities the health professionals can innovate, produce care and act as the protagonist subjects. In this sense, the innovation in the policy transfer of DOT can come from the recognition that the normativity of work always imposes a set of constraints and limits, but health workers are not doomed to reproduce it, and based on their experience, may produce changes that bring together the technological, interactive and intersubjective dimensions of their practices ${ }^{(27)}$.

In this sense, the ideas and attitudes about DOT can express greater freedom when choosing the way of producing health acts, by individual therapeutic projects that express the inter-subjectivity of the person in DOT and of health professionals with greater autonomy and self-government.

In Brazil, the supervised treatment has been happening for over a decade and a half with good results, but there is criticism of this modality due to the possibility of infantilizing or embarrassing TB patients ${ }^{(6)}$. When an interviewed participant said that the social benefit encourages continuity of care, but at the same time weakens the responsability sense of users with their health, the issue of hypo-sufficiency of subjects was raised, even though DOT is considered less restrictive than hospitalization ${ }^{(9)}$.

In general, the empowerment of health professionals and users is the factor that most consistently contributes with a space of innovation in the policy transfer of DOT. However, some FHS professionals still face adverse conditions in everyday work, such as insecurity in employment contract and the few spaces for qualification processes from the perspective of continuing education in health. All this affects the teamwork and the transformative creativity of these agents of change. On the other hand, some TB patients are still affected by the authoritarianism governing the asymmetric relationships between health professionals and users, who poorly develop their autonomy, citizenship and empowerment.

\section{CONCLUSION}

According to the nurses participating in the present study, it was observed that the transfer of DOT for the FHS contributed to a new organization of the health service in managing the actions to control TB. The actions of nurses in the treatment of disease are clear. It was also found that the actions developed under this treatment modality gave visibility to the work of nurses and professionals of the family health strategy who work under their supervision, like the community health agents and the nursing technicians. Based on this study, the leadership of nurses becomes visible when it comes to carrying out DOT for the control of TB.

Regarding the projections of the study participants in the perspective of improving this treatment modality as a policy transferred to the context of FHS, they provided suggestions that point to important innovations, including those affecting the basic principles of SUS, such as the theme of intersectoriality, the autonomy of patients, which is severily criticized in the aspect of infantilization by drug supervision, and the associated use of media technology, in this case, the coordination of assistance by the use of Web-TB.

It was found that the speeches on DOT are related to the monitoring of users, which creates bonding and increases the probability of the therapeutic outcome of cure. For the study participants, DOT approximates the health care team of the social and family contexts of users and, in this relation, the community health agents stand out for their work of observing the medication intake at home.

The two main points of emphasis regarding the contribution of nursing to DOT were the role of nurses as health educators and their ability to develop emotional bonds with users. Another highlight was the leadership competency that nurses have developed in their teamwork in the FHS.

The analyzes of this study are contextualized in the political-administrative and social reality of the capital of the first Brazilian state to implement DOTS, which can be considered a limitation of the study. Despite this fact, the depth of qualitative analysis combined with the comprehensiveness of the investigated subject and the innovative theoretical reference provide results with potential contributions to the advancement of nursing as a science, whether in teaching
Nursing performance in the policy transfer of directly observed treatment of tuberculosis Souza KMJ, Sá LD, Silva LMC, Palha PF 
and research activities, as in management or care practices of nurses in the FHS. Also, the approach of this study does not exhaust the possibilities of analyzing the issue under the framework of policy transfer. Hence, it is important to extend the research from the point of view of other change agents of the DOT policy, such as community health agents, managers of basic health units, managers in local, state and federal levels, and TCP coordinators.

\section{REFERENCES}

1. Boletim Epidemiológico. Brasília: Ministério da Saúde; Secretaria de Vigilância em Saúde. 2013;44(2).

2. Getahun B, Ameni G, Medhin G, Biadgilign S. Treatment outcome of tuberculosis patients under directly observed treatment in Addis Ababa, Ethiopia. Braz J Infect Dis. 2013;17(5):521-8.

3. Sá LD, Oliveira AAV, Gomes ALC, Nogueira JA,Villa TCS, Collet S. Caring for tuberculosis patients in the Family Health Strategy: the nurses' perceptions Rev Esc Enferm USP. 2012;46(2):356-63.

4. González C, Sáenz C, Herrmann E, Jatai M, Kaplan P, Monzón D. Tratamiento directamente observado de la tuberculosis en un hospital de la Ciudad de Buenos Aires. Medicina (B Aires). 2012;72(5): 371-9.

5. Ferreira V, Brito C, Portela M, Escosteguy C, Lima S. DOTS in primary care units in the city of Rio de Janeiro, Southeastern Brazil. Rev Saúde Pública. 2011;45(1):40-8.

6. Queiroz EM, De-La-Torre-Ugarte-Guanilo MC, Ferreira KR, Bertolozzi MR. Tuberculosis: limitations and strengths of Directly Observed Treatment Short-Course. Rev Latino Am Enfermagem. 2012;20(2):369-77.

7. Palha PF, Villa TCS, Ruffino Netto A, Protti ST, Silva LMC, Weiller TH, et al. Tratamento diretamente observado (DOT): sustentabilidade no controle da tuberculose em municípios prioritários do Estado de São Paulo, 1998-2004. In: Villa TCS, Ruffino-Netto A. Tuberculose: pesquisas operacionais. Ribeirão Preto: FUNPEC; 2009. p.194-206.

8. Gazetta CE, Vendramini SHF, Ruffino-Netto A, Oliveira MRC, Villa TCS. Descriptive study of the implementation and impact of the directly observed treatment, short-course strategy in the São José do Rio Preto municipal tuberculosis control program (1998-2003). J Bras Pneumol. 2007;33(2):192-8.

9. Queiroz EM, Bertolozzi MR. Tuberculosis: supervised treatment in North, West and East Health Departments of São Paulo. Rev Esc Enferm USP [Internet]. 2010 [cited 2014 Apr 26]; 44(2):453-61. Available from: http://www.scielo.br/pdf/ reeusp/v44n2/en_30.pdf

10. Sá LD, Andrade MN, Nogueira JA, Villa TCS, Figueiredo TMRM, Queiroga RPF, et al. Implantação da estratégia DOTS no controle da tuberculose na Paraíba: entre o compromisso político e o envolvimento das equipes do programa saúde da família (1999-2004). Ciênc Saúde Coletiva. 2011;16(9):3917-24.
11. Oblitas FYM, Loncharich N, Salazar ME, David HML, Silva I, Velásquez D. Nursing's role in tuberculosis control: a discussion from the perspective of equity. Rev Latino Am Enfermagem. 2010;18(1):130-8.

12. Bissell K, Lee K, Freeman R. Analysing policy transfer: perspectives for operational research. Int J Tuberc Lung Dis. 2011;15(9):1140-8.

13. Zachariah R, Harries AD, Ishikawa N, Rieder HL, Bissell K, Laserson $\mathrm{K}$, et al. Operational research in low-income countries: what, why, and how? Lancet Infect Dis. 2009;9(11):711-7.

14. São Paulo (Cidade). Secretaria Municipal de Saúde; Coordenação de Epidemiologia e Informação (CEInfo). Diagnóstico sintético da saúde na cidade de São Paulo [Internet]. São Paulo; 2011 [citado 2014 abr. 26]. Disponível em: http://www.prefeitura.sp.gov.br/cidade/secretarias/upload/saude/arquivos/ publicacoes/DiagnosticoSinteticoSaudeCidadeSaoPaulo.pdf.

15. Fontanella BJB, Ricas J, Turato ER. Amostragem por saturação em pesquisas qualitativas em saúde: contribuições teóricas. Cad Saúde Pública. 2008;24(1):17-27.

16. Bardin L. Análise de conteúdo. Lisboa: Edições 70; 2009.

17. Dolowitz D, Marsh D. Who learns what from whom: a review of the policy transfer literature. Polit Stud (Oxf). 1996;44(2):343-57.

18. Turgeon J, Gagnon F, Michaud M, Tremblay S. Policy health transfer and health impact assessment. Québec: Groupe d'Étude sur les Politiques Publiques et la Santé; 2008.

19. Hino P, Bertolozzi MR, Takahashi RF, Egry EY. Health needs according to the perception of people with pulmonary tuberculosis. Rev Esc Enferm USP [Internet]. 2012 [cited 2014 Apr 26];46(6):1438-45. Available from: http://www.scielo. $\mathrm{br} / \mathrm{pdf} /$ reeusp/v46n6/en_22.pdf

20. Sá LD, Gomes ALC, Nogueira JA, Villa TCS, Souza KMJ, Palha PF. Intersectorality and bonding in tuberculosis control in Family Health. Rev Latino Am Enfermagem. 2011;19(2):387-95.

21. Souza KMJ, Sá LD, Palha PF, Nogueira JA, Villa TCS, Figueiredo DA. Tuberculosis treatment drop out and relations of bonding to the family health team. Rev Esc Enferm USP [Internet]. 2010 [cited 2014 Apr 26];44(4):904-11. Available from: http://www.scielo.br/pdf/reeusp/v44n4/en_07.pdf 
22. Gomes ALC, Sá LD. As concepções de vínculo e a relação com o controle da tuberculose. Rev Esc Enferm USP. 2009;43(2):365-72.

23. Silva ACO, Sousa MCM, Nogueira JA, Motta MCS. Tratamento supervisionado no controle da tuberculose: potencialidades e fragilidades na percepção do enfermeiro. Rev Eletr Enferm [Internet]. 2007 [citado 2014 abr. 26];9(2):402-416. Disponível em: http://www.fen.ufg.br/fen_revista/v9/n2/ pdf/v9n2a09.pdf

24. Ibanês AS, Carneiro Junior N. Panorama internacional e nacional da estratégia do tratamento diretamente supervisionado (DOTS) nas políticas de controle da tuberculose. ABCS Health Sci. 2013;38(1):25-32.
25. Brasil. Ministério da Saúde; Secretaria de Vigilância em Saúde. Programa Nacional de Controle da Tuberculose. Manual de recomendações para o controle da tuberculose no Brasil. Brasília; 2010.

26. Backes DS, Backes MS, Erdmann AL, Büscher A. O papel profissional do enfermeiro no Sistema Único de Saúde: da saúde comunitária à Estratégia de Saúde da Família. Ciênc Saúde Coletiva. 2012;17(1):223-30.

27. Carvalho BG, Peduzzi M, Mandú ENT, Ayres JRCM. Work and inter-subjectivity: a theoretical reflection on its dialectics in the field of health and nursing. Rev Latino Am Enfermagem. 2012;20(1):19-26.

\section{Financial support}

Conselho Nacional de Desenvolvimento Científico e Tecnológico (CNPq). 